\title{
Differential effects of GH and GH-releasing peptide- 6 on astrocytes
}

\author{
Eva Baquedano ${ }^{1,3}$, Julie A Chowen ${ }^{2,3}$, Jesús Argente ${ }^{1,2,3}$ and Laura M Frago 1,3 \\ ${ }^{1}$ Department of Pediatrics, Universidad Autónoma de Madrid, Madrid, Spain \\ ${ }^{2}$ Department of Endocrinology, Hospital Infantil Universitario Niño Jesús-UAM, Instituto de Investigación La \\ Princesa, Avenida Menéndez Pelayo 65, 28009 Madrid, Spain \\ ${ }^{3}$ Centro de Investigación Biomédica en Red de fisiopatología de la obesidad y nutrición (CIBERobn), \\ Instituto de Salud Carlos III, Madrid, Spain
}

\author{
Correspondence \\ should be addressed \\ to L M Frago \\ Email \\ laura.frago@uam.es
}

\begin{abstract}
GH and GH secretagogues (GHSs) are involved in many cellular activities such as stimulation of mitosis, proliferation and differentiation. As astrocytes are involved in developmental and protective functions, our aim was to analyse the effects of $\mathrm{GH}$ and $\mathrm{GH}$-releasing hexapeptide on astrocyte proliferation and differentiation in the hypothalamus and hippocampus.

Treatment of adult male Wistar rats with GH (i.v., $100 \mu \mathrm{g} /$ day) for 1 week increased the levels of glial fibrillary acidic protein (GFAP) and decreased the levels of vimentin in the hypothalamus and hippocampus. These changes were not accompanied by increased proliferation.

By contrast, GH-releasing hexapeptide (i.v., $150 \mu \mathrm{g} /$ day) did not affect GFAP levels but increased proliferation in the areas studied. To further study the intracellular mechanisms involved in these effects, we treated $\mathrm{C} 6$ astrocytoma cells with GH or GH-releasing hexapeptide and the phosphatidylinositol 3'-kinase (PI3K) inhibitor, LY294002, and observed that the presence of this inhibitor reverted the increase in GFAP levels induced by GH and the proliferation induced by GH-releasing hexapeptide. We conclude that although GH-releasing hexapeptide is a GHS, it may exert $\mathrm{GH}$-independent effects centrally on astrocytes when administered i.v., although the effects of both substances appear to be mediated by the PI3K/Akt pathway.
\end{abstract}

\section{Key Words}

$\checkmark \mathrm{GH}$

- GHRP-6

- hippocampus

- hypothalamus

- proliferation

- differentiation

\section{Introduction}

It is well established that $\mathrm{GH}$, one of the main regulators of growth and metabolism (Conway-Campbell et al. 2007, Lichanska \& Waters 2008), also has profound effects in the CNS (Harvey et al. 1993, Nyberg 2000, Donahue et al. 2006), being involved in the regulation of emotion (Burman \& Deijen 1998), cognitive functions, memory (Deijen et al. 2011), appetite (Stoving et al. 1999) and neuroprotection (Scheepens et al. 1999, Frago et al. 2002, Lyuh et al. 2007). Indeed, the GH receptor (GHR) is expressed in diverse areas throughout the CNS (Fraser et al. 1990, Le Greves et al. 2005) where this hormone has been shown to be involved in numerous cellular activities such as stimulation of mitosis, cell proliferation and differentiation (Frago et al. 2002, Ajo et al. 2003). Binding of GH to its receptor mediates many of its effects through activation of the JAK/STAT signalling pathway (Lanning \& Carter-Su 2006); however, GHR is also able to signal through additional pathways including the MAPK and the phosphatidylinositol 3'-kinase (PI3K; Brooks et al. 2008) pathways.

Release of $\mathrm{GH}$ from the anterior pituitary can be stimulated by ghrelin, as well as by its analogues the GH

Published by Bioscientifica Ltd. 
secretagogues (GHSs), which include GH-releasing peptides (GHRP)-1, -2 and -6. Both ghrelin and GHSs bind to GHS receptors not only expressed in the pituitary but also widely distributed in the CNS (Ghigo et al. 2001, Zigman et al. 2006, Frago et al. 2011). Upon binding to the GHS receptor, which has been renamed ghrelin receptor (GRLN-R1a; Davenport et al. 2005), GHSs activate pathways that regulate the activation of downstream MAPK, protein kinase B (PKB/Akt), nitric oxide synthase and adenosine monophosphate-activated protein kinase cascades in different cellular systems (Petersenn 2002). GRLN-R1a activation leads to an increase in intracellular levels of $\mathrm{Ca}^{2+}$ via phosphatidylinositol-specific phospholipase C (Camiña et al. 2003, Muccioli et al. 2007). Ghrelin and GHRP-6 stimulate proliferation of different cell types (Dieguez \& Casanueva 2000, Pettersson et al. 2002, Thompson et al. 2004, Rossi et al. 2009) and may also affect the CNS by protecting neurons from apoptosis (Frago et al. 2002, 2011, Delgado-Rubin de Célix et al. 2006, Delgado-Rubin et al. 2009).

Astrocytes comprise a heterogeneous family of morphologically and functionally distinct cells whose structural plasticity is mostly maintained by a filamentous network mainly consisting of vimentin and glial fibrillary acidic protein (GFAP; Gomes et al. 1999a, Järlestedt et al. 2010). Astrocytes have a variety of active roles in maintaining normal brain physiology (Barres 1991, Perea $\&$ Araque 2005). Proliferation and differentiation of astrocytes are related in part to the modulation of GFAP expression during CNS development by the regulation of Gfap gene promoter (Gomes et al. 1999b).

As glial cells express GHR (McLenachan et al. 2009) and astrocytes in GHR-deficient mice are smaller and less abundant (List et al. 2011), our aim was to analyse the effects of GH and GHRP- 6 on astrocyte proliferation and differentiation. In addition, as rats treated with $\mathrm{GH}$ or GHRP-6 showed increased levels of phosphorylated Akt in the hypothalamus, hippocampus and cerebellum, but not of ERKs1/2 (Frago et al. 2002), and Akt is a central regulator of survival, growth and proliferation (Pascual \& Guerri 2007), we evaluated the possible involvement of Akt in these processes.

\section{Materials and methods}

\section{Materials}

All chemicals were purchased from Sigma Chemical unless otherwise noted. Antibodies to GFAP were from Sigma. The antibody to pan-phospho-Ser was from Calbiochem
(La Jolla, CA, USA), and antibodies to phospho-STAT5 and MAPK $1 / 2$ were from Upstate (Lake Placid, NY, USA). The antibody to STAT5 was from Thermo Fisher Scientific (Waltham, MA, USA), to proliferating cell nuclear antigen (PCNA) from Signet (Dedham, MA, USA), to vimentin from Dakocytomation (Glostrup, Denmark), to BIII-tubulin (Tuj1) from R\&D Systems (Minneapolis, MN, USA), to phospho-Akt and phospho-p44/42 MAPK (ERK1/2; Thr202/Tyr204) from Cell Signalling Technology (Danvers, MA, USA), and to Akt, GHR and GHS-R1a (GRLN-R1a) from Santa Cruz Biotechnology, Inc. Secondary antibodies conjugated to peroxidase were from Thermo Fisher Scientific.

\section{Methods}

Animals Male Wistar rats (Charles River, Margate, UK) weighing 200-250 g were used for all experiments. The animals were treated according to the European Community laws for animal care, and studies were approved by the institutional ethics committee. Rats were infused with GH (Novo Nordisk, Bagsvaerd, Denmark; $100 \mu \mathrm{g} /$ day) or GHRP-6 (Bachem, Bubendorf, Switzerland; $150 \mu \mathrm{g} /$ day) using Alzet minipumps $(1 \mu \mathrm{l} / \mathrm{h}, 7 \mathrm{~d})$ connected to the jugular vein. Control animals received a minipumpdelivering vehicle (saline) at the same infusion rate. Rats ( $n=6$ in each group) were killed by decapitation and brains were immediately removed and frozen on dry ice.

For immunofluorescence studies, three control rats were perfused transcardially with phosphate-buffered $4 \%$ paraformaldehyde $(\mathrm{pH}$ 7.4) under pentobarbital anaesthesia $(1 \mathrm{mg} / \mathrm{kg})$. The brains were postfixed overnight at $4{ }^{\circ} \mathrm{C}$ and then stored in cryoprotection solution $(30 \%(\mathrm{w} / \mathrm{v})$ sucrose and $30 \%(\mathrm{v} / \mathrm{v})$ ethylene glycol in phosphate buffer) at $-20^{\circ} \mathrm{C}$.

Cell culture All cell culture material was purchased from Gibco (Invitrogen Co.). GH was from Pharmacia, GHRP-6 and D-Lys3-GHRP-6 were from Bachem, antibody to GHR was from R\&D Systems and LY294002 was from Calbiochem.

Stock cultures of the astrocyte cell line C6 were routinely grown in $100 \mathrm{~mm}$ culture dishes (Becton Dickinson Labware, Franklin Lakes, NJ, USA) in DMEM (Invitrogen) with $4.5 \mathrm{~g} / \mathrm{l}$ D-glucose without phenol red supplemented with $10 \%(\mathrm{v} / \mathrm{v})$ foetal bovine serum (FBS), $100 \mathrm{U} / \mathrm{ml}$ penicillin-streptomycin and glutamine $\left(200 \mathrm{~mol} / \mathrm{l}^{3}\right)$. The cells were grown at $37{ }^{\circ} \mathrm{C}$ in a humidified atmosphere of $5 \% \mathrm{CO}_{2}$ in air.

Published by Bioscientifica Ltd 
Hormonal treatment of astrocyte cell line For all experiments, cells were plated in $100 \mathrm{~mm}$ dishes, $60 \mathrm{~mm}$ culture dishes or 24-well plates for $72 \mathrm{~h}$ in DMEM containing $10 \%(\mathrm{v} / \mathrm{v})$ FBS and then in DMEM without FBS but containing $1 \mathrm{~mol} / \mathrm{l}^{3}$ cAMP. Cultures were maintained for $48 \mathrm{~h}$ in this differentiation medium without FBS. Subsequently, the cells were treated with $5,10,25$ or $50 \mu \mathrm{g} / \mathrm{ml} \mathrm{GH}\left(226.24 \mathrm{~mol} / \mathrm{l}^{9}, 452.49 \mathrm{~mol} / \mathrm{l}^{9}, 1.13 \mathrm{~mol} / \mathrm{l}^{6}\right.$ and $2.26 \mathrm{~mol} / \mathrm{l}^{6}$ respectively); 10,25 or $50 \mu \mathrm{g} / \mathrm{ml}$ GHRP-6 $\left(11.45,28.63\right.$ and $57.27 \mathrm{~mol} / \mathrm{l}^{6}$ respectively); antibody to GHR $(0.3 \mu \mathrm{g} / \mathrm{ml})$; D-Lys3-GHRP-6 $\left(50 \mathrm{~mol} / \mathrm{l}^{6}\right)$ and/or LY294002 $\left(50 \mathrm{~mol} / \mathrm{l}^{6}\right)$ for $24 \mathrm{~h}$. Three different experiments were performed in duplicate, except crystal violet assay where four different experiments were performed in quadruplicate.

Protein extraction and quantification For western blotting, $\sim 100 \mathrm{mg}$ hypothalamus or hippocampus were homogenised in $500 \mu$ l radioimmunoprecipitation assay lysis buffer with an EDTA-free protease inhibitor cocktail (Roche Diagnostics). After homogenisation, the samples were centrifuged at $12000 \boldsymbol{g}$ for $5 \mathrm{~min}$ at $4{ }^{\circ} \mathrm{C}$ to remove the insoluble material. Clear supernatants were transferred to a new tube to measure protein content.

Protein of cell culture was extracted in a different way. Cells were collected in $100 \mu \mathrm{l}$ Laemmli buffer with $10 \mu \mathrm{l}$ phenylmethylsulphonyl fluoride and then were sonicated. Protein concentration was estimated by the method of Bradford (Bio-Rad Laboratories, Inc.).

Immunoblotting Thirty or $60 \mu \mathrm{g}$ protein obtained from hypothalamus or hippocampus or $20 \mu \mathrm{l}$ cells' proteins were resolved using 10\% (w/v) SDS-PAGE and then transferred onto polyvinylidene difluoride membranes (Bio-Rad Laboratories, Inc.). Filters were blocked with Tris-buffered saline (TBS) containing 5\% (w/v) nonfat dried milk, except for phosphorylated proteins where TBS containing 5\% (w/v) BSA was used and incubated with the primary specific antibody at a dilution of 1:1000. Filters were subsequently washed and incubated with the corresponding secondary antibody conjugated with peroxidase at a dilution of 1:2000. Bound peroxidase activity was visualised by chemiluminescence using an ImmunStar WesternC kit (Bio-Rad). Quantification of the bands obtained was carried out by densitometry using a Kodak Gel Logic 1500 Image Analysis system and Molecular Imaging Software version 4.0 (Rochester, NY, USA). All blots were re-blotted with actin to normalise each sample for gel-loading variability.
Immunofluorescence Immunohistochemistry was performed on vibratome $50 \mu \mathrm{m}$ free-floating sections of paraformaldehyde-perfused control rats. Sections were washed in $0.1 \mathrm{~mol} / \mathrm{l} \mathrm{PB}\left(\mathrm{K}_{2} \mathrm{HPO}_{4}\right.$ and $\mathrm{NaH}_{2} \mathrm{PO}_{4}, \mathrm{pH}$ 7.4) for 10 min and then washed four times in PBT containing $0.3 \% \mathrm{v} / \mathrm{v}$ Triton $\mathrm{X}-100$ and $0.3 \% \mathrm{w} / \mathrm{v}$ BSA in $0.1 \mathrm{~mol} / \mathrm{l} \mathrm{PB}$ for $10 \mathrm{~min}$; afterwards, sections were left for $48 \mathrm{~h}$ at $4{ }^{\circ} \mathrm{C}$ with the primary antibody for GFAP (1:500, mouse) and GHR or GRLN1a (1:500, rabbit) in blocking solution. Afterwards, sections were washed and incubated with Alexa-633-conjugated anti-mouse and Alexa-488-conjugated anti-rabbit antibodies (Thermo Fisher Scientific; 1:500 dilution) for $90 \mathrm{~min}$ at RT and mounted with crystal mount. Signal was visualised using a confocal microscope (Leica Corp., Madrid, Spain).

\section{Immunoenzymometric assay for determination of}

IGF1 The quantitative determination of serum IGF1 was performed with the OCTEIA immunoenzymometric assay (IEMA) from IDS, Immunodiagnostic Systems Limited (Boldon, Tyne \& Wear, UK), developed in association with GroPep Limited (Adelaide, South Australia). The method was performed according to the manufacturer's instructions. Briefly, serum samples were incubated with a reagent to inactivate binding proteins (10 $\mathrm{min}, 25^{\circ} \mathrm{C}$ ) and then diluted for assay. In the OCTEIA rat/mouse IGF1 kit, a purified monoclonal anti-rat IGF1 is coated onto the inner surface of polystyrene microtitre wells (the solid phase or capture antibody). The pretreated, diluted samples were then incubated with biotinylated polyclonal rabbit anti-rat IGF1 in antibody-coated wells and shaken for $2 \mathrm{~h}$ at room temperature $\left(25^{\circ} \mathrm{C}\right)$. The wells were washed and enzyme (HRP) labelled avidin, which binds to the biotin complex, was added $\left(30 \mathrm{~min}, 25^{\circ} \mathrm{C}\right)$. After washing, a single-component chromogenic substrate (a formulation of tetramethylbenzidine) was added to develop colour $\left(30 \mathrm{~min}, 25^{\circ} \mathrm{C}\right)$. The absorbance of the stopped reaction mixture was read $(450 \mathrm{~nm}$; reference $650 \mathrm{~nm}$ ) in a microtitre plate reader, with colour intensity being directly proportional to the amount of rat IGF1 present in the sample. This assay has a sensitivity limit of $63 \mathrm{ng} / \mathrm{ml}$. The intra- and interassay coefficients of variation were 6.8 and 7.3 respectively.

Crystal violet assay Cells were grown and differentiated in 24-well culture dishes, and after $24 \mathrm{~h}$ of exposure to different treatments, the medium was removed and the cells were fixed with $1 \%(\mathrm{v} / \mathrm{v})$ glutaraldehyde for $20 \mathrm{~min}$ at $25^{\circ} \mathrm{C}$. After washing with PBS, $0.1 \%$ crystal violet was added to each well for $20 \mathrm{~min}$ at $25^{\circ} \mathrm{C}$. The wells were then

Published by Bioscientifica Ltd 
washed under running water for $20 \mathrm{~min}$. After drying, $2 \mathrm{ml} \mathrm{8 \%} \mathrm{(v/v)} \mathrm{acetic} \mathrm{acid} \mathrm{was} \mathrm{added} \mathrm{to} \mathrm{each} \mathrm{well.} \mathrm{The}$ intensity of the resulting colour was measured at $590 \mathrm{~nm}$ on an automatic microplate analyser (TECAN Infinite M200, Grödig, Austria).

RNA extraction Total RNA was extracted from cultured astrocytes after $24 \mathrm{~h}$ of exposure to $\mathrm{GH}(5,10$, 25 and $50 \mu \mathrm{g} / \mathrm{ml})$ or GHRP- $6(10,25$ and $50 \mu \mathrm{g} / \mathrm{ml})$ following the instructions of TriReagent (Invitrogen). Briefly, cells were homogenised in $1 \mathrm{ml}$ TriReagent and incubated for $5 \mathrm{~min}$ at $25^{\circ} \mathrm{C}$ to dissociate nucleoprotein complexes. Chloroform $(0.2 \mathrm{ml})$ was added and the samples were shaken vigorously for $15 \mathrm{~s}$ and incubated for $15 \mathrm{~min}$ at $25^{\circ} \mathrm{C}$. Tubes were centrifuged at $12000 \mathrm{~g}$ for $15 \mathrm{~min}$ at $4{ }^{\circ} \mathrm{C}$. The aqueous phase was transferred to new tubes and isopropanol $(0.5 \mathrm{ml})$ was added to precipitate RNA. Samples were incubated for $10 \mathrm{~min}$ at $25^{\circ} \mathrm{C}$ and then centrifuged at $12000 \mathrm{~g}$ for $10 \mathrm{~min}$ at $4^{\circ} \mathrm{C}$. The supernatants were removed and the pellets were washed in $1 \mathrm{ml}$ of $75 \%$ (v/v) ethanol. After vortexing, samples were centrifuged at $7500 \mathrm{~g}$ for $5 \mathrm{~min}$ at $4{ }^{\circ} \mathrm{C}$. Pellets were air-dried, dissolved in RNAse-free water and absorbance at $260 \mathrm{~nm}$ was measured to determine concentrations.

Real-time RT-PCR cDNA was synthesised from $2 \mu \mathrm{g}$ total RNA using the high-capacity cDNA reverse transcription kit (Applied Biosystems). Quantitative realtime PCR was performed using assay-on-demand kits (Applied Biosystems) for GHR (Rn00567298_m1), GRLNR1a (Rn00821417_m1) and IGF1 (Rn99999087_m1) and TaqMan Universal PCR Master Mix (Applied Biosystems) according to the manufacturer's protocol in an ABI PRISM 7000 Sequence Detection System (Applied Biosystems) with conventional Applied Biosystems cycling parameters (40 cycles for $95^{\circ} \mathrm{C}, 15 \mathrm{~s}: 60^{\circ} \mathrm{C}, 1 \mathrm{~min}$ ). Values were normalised to the housekeeping gene Gapdh (Rn99999916-s1). According to the manufacturer's guidelines, the $\Delta \Delta C_{\mathrm{T}}$ method was used to determine relative expression levels. Statistical analyses were performed using $\Delta \Delta C_{\mathrm{T}}$ values.

Statistical analysis Protein samples from each animal were analysed in three different assays and the mean value was used for statistical analysis $(n=$ number of animals in each group). Individual culture dishes or wells were analysed separately (no pooling of samples was used). In each experiment, a minimum of two wells of each treatment were used. Each in vitro experiment was repeated a minimum of three times. In each experiment, the mean value of the repetitions was calculated, and this value was used in the statistical analysis. All data were normalised to control values of each assay and are presented as mean \pm s.E.M. Data were analysed by oneway ANOVA followed by a Bonferroni test using the statistical program GraphPad Prism 4.0 (GraphPad Software, San Diego, CA, USA). Significance was chosen as $P<0.05$.

\section{Results}

\section{GH increases GFAP levels in the hypothalamus and hippocampus of rats}

Immunoblots for GFAP were prepared from hypothalamus and hippocampus homogenates of rats treated with $\mathrm{GH}$ or GHRP-6. GH increased GFAP levels in the hypothalamus (150\% of control levels) and hippocampus (228\% of control levels, Fig. 1A). A shift in the electrophoretic mobility of GFAP bands was observed in samples from GH-treated rats. No significant changes were observed in response to GHRP-6.
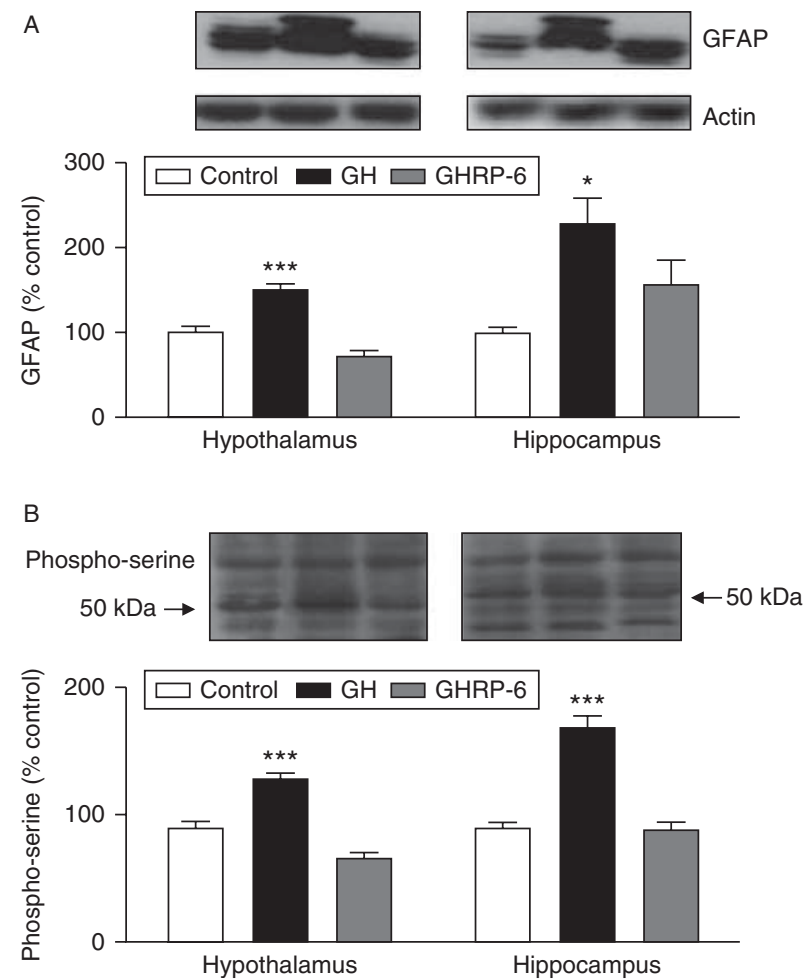

Figure 1

Relative levels of GFAP (A) and phospho-serine (B) proteins in the hypothalamus and hippocampus of control rats, rats treated with $\mathrm{GH}$ and rats treated with GHRP-6. Statistical significance by ANOVA: ${ }^{*} P<0.05$ and $\star * * P<0.001$ vs control; $n=6 /$ group.

Published by Bioscientifica Ltd 


\section{GH increased the phosphorylation of serine residues in the hypothalamus and hippocampus}

In order to analyse the shift in electrophoretic mobility observed in samples from GH-treated rats, the serine phosphorylation pattern was studied using an antibody that recognised phosphorylations on serine residues. Increased labelling in phospho-Ser was coincident with GFAP shifting observed in GH-treated samples. PhosphoSer levels increased $143 \%$ in the hypothalamus and $190 \%$ in the hippocampus compared with control levels. No significant changes were observed in response to GHRP-6. (Fig. 1B).
A

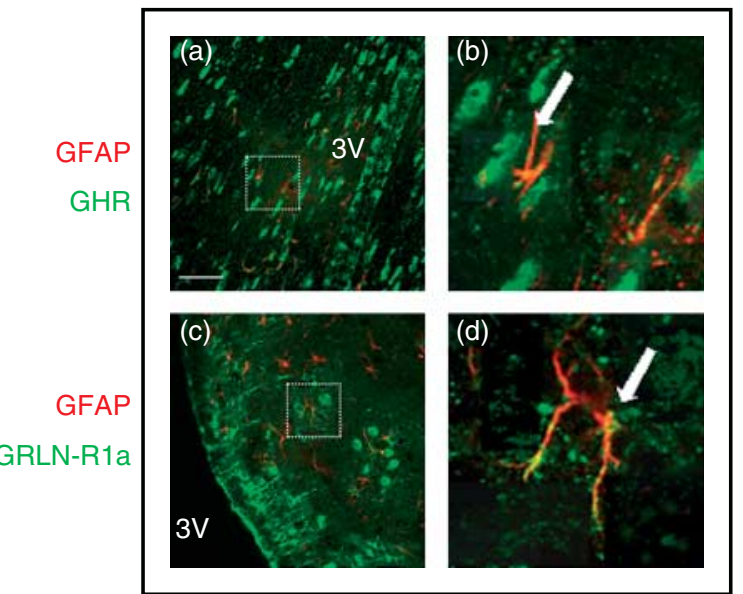

B

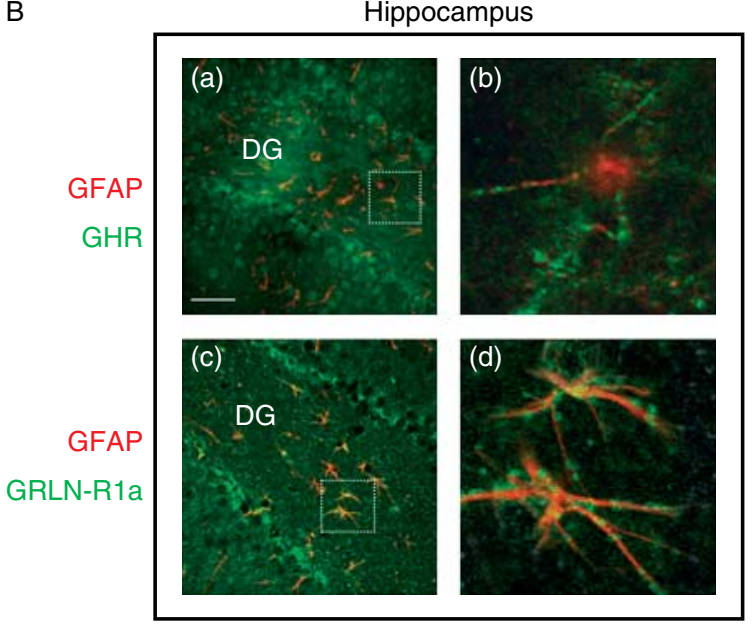

Figure 2

Co-immunostaining for GFAP and GHR and for GFAP and GRLN-R1a in hypothalamus (A) and hippocampus (B) of control rats. Scale bar: $50 \mu \mathrm{m}$ ( $a$ and $c$ ) or $100 \mu \mathrm{m}$ (b and d). Panels $b$ and $d$ are a higher magnifications of $a$ and $c$ respectively and indicated by dotted squares. Arrows indicate astrocytes expressing GHR or GRLN-R1a.

\section{GFAP and GH or GRLN-R1a receptor immunohistochemistry}

To confirm the presence of GHR and GRLN-R1a in astrocytes of the hypothalamus and hippocampus, double-immunofluorescence labelling studies were performed. Co-localisation of GHR and GFAP and colocalisation of GRLN-R1a and GFAP were observed in the arcuate nucleus of the hypothalamus (Fig. 2A). Labelling for GRLN-R1 was observed in tanycytes, in the specialised glial cells lining the third ventricle (Fig. 2A, photomicrograph c) and in neurons throughout the periventricular areas. The median eminence showed labelling for GFAP but not for GHR or GRLN-R1a (data not shown). In the hippocampus, GFAP labelling was observed for both GHR and GRLN-R1a in the dentate gyrus (Fig. 2B). Neurons of the granular layer showed weak labelling for GHR and GRLN-R1a (Fig. 2B, microphotographs a and c).

\section{GH increases STAT5 levels in the hypothalamus and hippocampus}

Immunoblots of STAT5 and activated STAT5 (phosphorylated on Ser726/731) were prepared from hypothalamus and hippocampus homogenates of rats treated with GH and GHRP-6. Treatment with GHRP-6 did not activate STAT5 in any of the areas studied and treatment with GH resulted in activation of STAT5 in the hypothalamus (control: $100 \pm 14.3, \mathrm{GH}: 167.2 \pm 10.5$ and GHRP-6: 102.8 $\pm 7.8 ; P<0.05$ ) and hippocampus (control: $100 \pm 9.9$, GH: $152.1 \pm 15.04$ and GHRP-6: 102.8 \pm 7.8 ; $P<0.05)$. The amount of total STAT5a and -b was not altered by any of the treatments.

\section{Role of GH and GHRP-6 in cell proliferation and differentiation}

Cell proliferation was assayed by western blotting against the PCNA. Treatment with GH did not alter the amount of PCNA; however, treatment with GHRP-6 increased PCNA levels in the hypothalamus (318\% of control levels) and in the hippocampus (247\% of control levels) (Fig. 3A).

To study the possible role of GH and GHRP-6 in astrocyte differentiation, we measured vimentin levels. GH-treated rats had lower levels of vimentin in the hippocampus (58\% of control values) and in the hypothalamus, although not statistically significant $(75 \%$ of control levels). Treatment with GHRP-6 did not alter the levels of vimentin in these areas (Fig. 3B).

Published by Bioscientifica Ltd. 
A
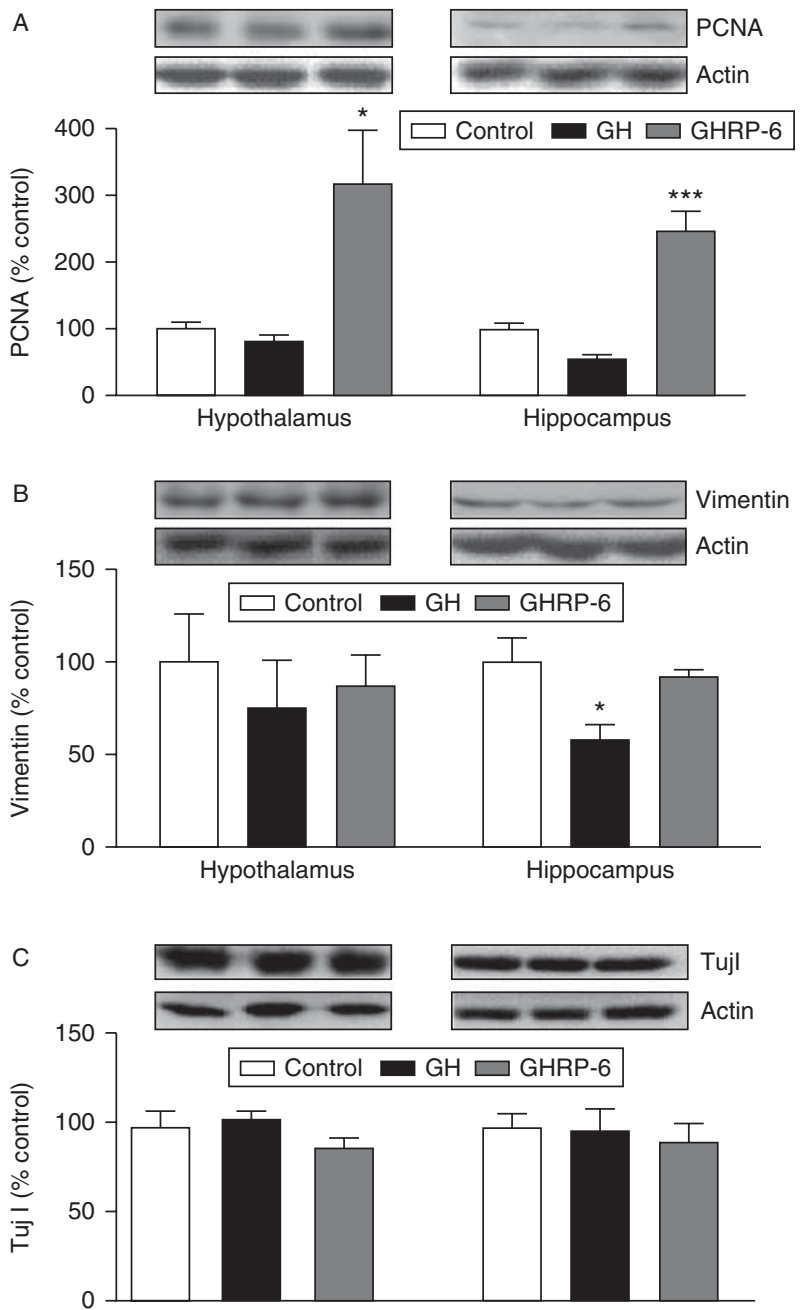

Figure 3

Relative levels of PCNA (A), vimentin (B) and Tuj1 (C) proteins in the hypothalamus and hippocampus of control rats, rats treated with $\mathrm{GH}$ and rats treated with GHRP-6. Statistical significance by ANOVA: ${ }^{*} P<0.05$ and $* * * P<0.001$ vs control; $n=6 /$ group.

To study the effects of GH and GHRP- 6 on neurons, we measured Tuj1 levels. Treatment with GH or GHRP-6 did not alter the levels of Tuj1 in the hypothalamus or hippocampus (Fig. 3C).

\section{GH and GHRP actions are not mediated by serum IGF1}

To assess whether the effects of GH and GHRP- 6 are not mediated by increased levels of circulating IGF1, we measured serum IGF1 levels in all experimental groups. IGF1 levels were not different from control levels in the rats treated with GH or GHRP-6 (controls: $1735 \pm$ $161 \mathrm{ng} / \mathrm{ml} ; \mathrm{GH}: 1589 \pm 89 \mathrm{ng} / \mathrm{ml}$ and GHRP-6: $1809 \pm$ $63 \mathrm{ng} / \mathrm{ml} ; P=0.413)$.

\section{Role of GH and GHRP-6 in C6 glioblastoma cell line}

To further investigate the actions of GH and GHRP-6 on astrocytes, we used the glioblastoma cell line C6. Doses-response curves were performed to detect the expression of GHR and GRLN-R1a by real-time RT-PCR and to determine the concentration to use. Twenty-five or $50 \mu \mathrm{g} / \mathrm{ml} \mathrm{GH}$ increased (162 and 181\% of control values respectively) the expression of GHR mRNA (Fig. 4A). As $25 \mu \mathrm{g} / \mathrm{ml}$ is the lowest dose that increased GHR expression, the subsequent assays were performed at this dose. Treatment with $25 \mu \mathrm{g} / \mathrm{ml} \mathrm{GH}$ resulted in statistically
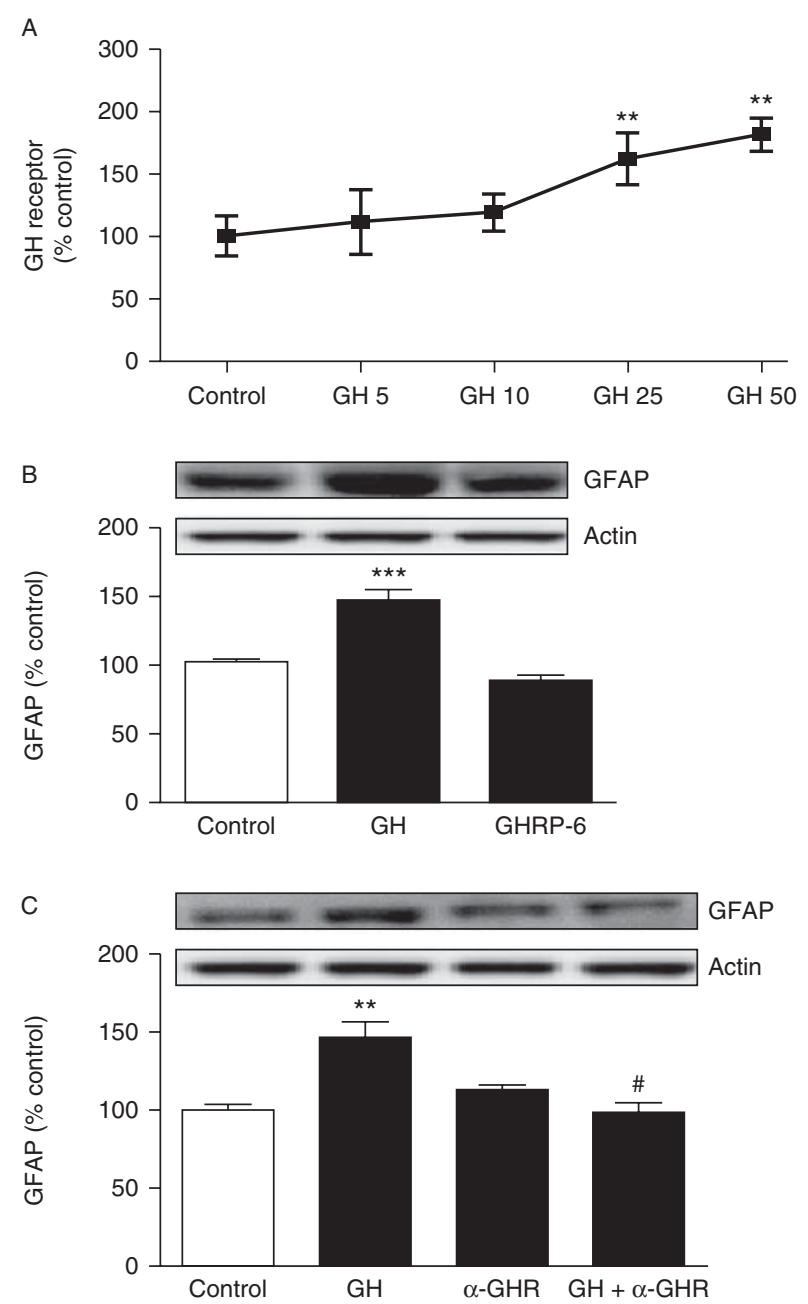

Figure 4

Relative levels of GHR mRNA in C6 cells treated with different doses $(5-50 \mu \mathrm{g} / \mathrm{ml})$ of GH (A). Relative levels of GFAP protein in cells treated with GH $(25 \mu \mathrm{g} / \mathrm{ml})$ or with GHRP- $6(25 \mu \mathrm{g} / \mathrm{ml})$ (B). Relative levels of GFAP protein in cells treated with $\mathrm{GH}(25 \mu \mathrm{g} / \mathrm{ml})$ or with a blocking antibody to GHR $(0.3 \mu \mathrm{g} / \mathrm{ml})(\mathrm{C})$. The mean of three independent experiments performed in duplicate is shown. Statistical significance by ANOVA: $* * P<0.01$ and $* * * P<0.001$ vs control; ${ }^{\#} P<0.05$ vs $\mathrm{GH}$.

Published by Bioscientifica Ltd. 

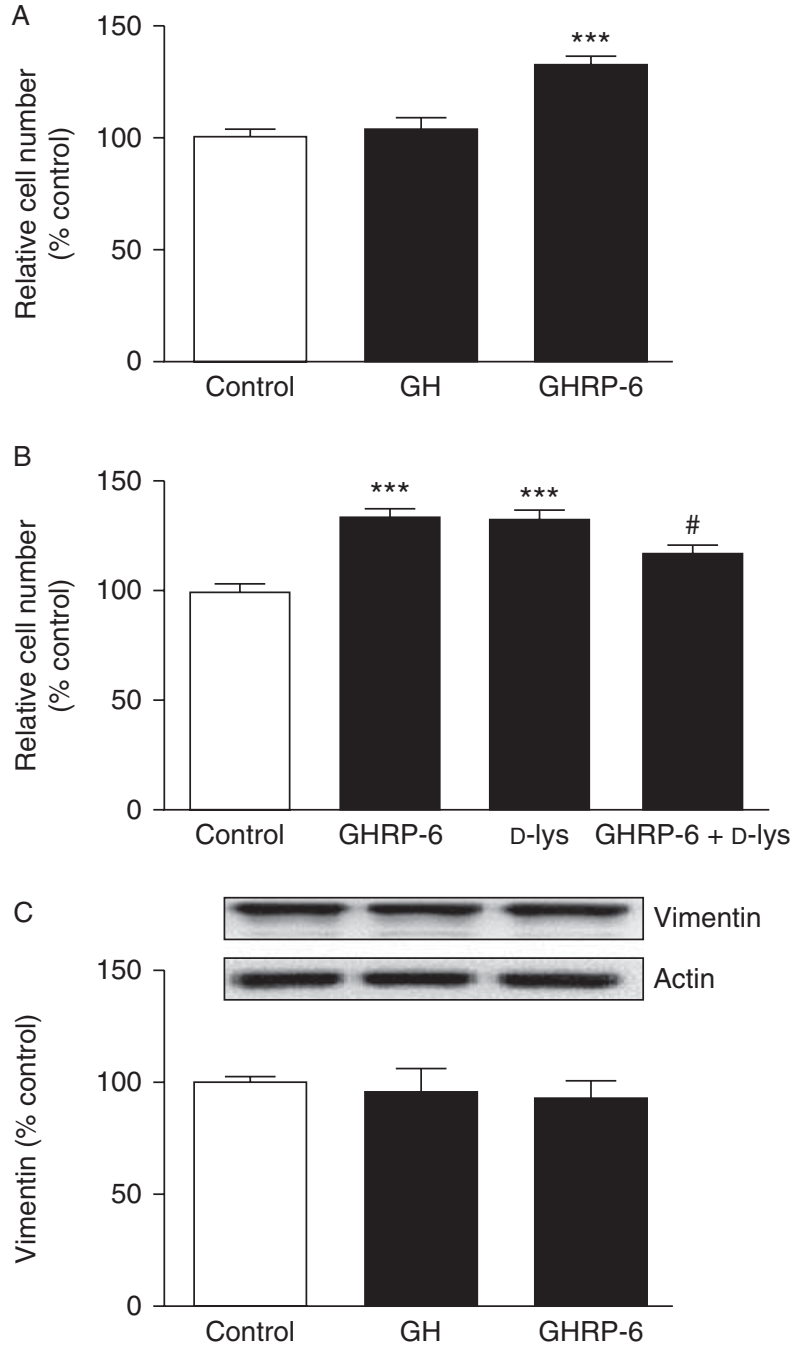

Figure 5

Quantification of cell viability assayed by crystal violet in $\mathrm{C} 6$ cells treated with GH $(25 \mu \mathrm{g} / \mathrm{ml})$ or with GHRP-6 $(25 \mu \mathrm{g} / \mathrm{ml})$ (A). Quantification of cell viability assayed by crystal violet in C6 cells treated with GHRP-6 $(25 \mu \mathrm{g} / \mathrm{ml})$ or with D-Lys3-GHRP-6 (50 $\mu \mathrm{M})$ (B). Relative vimentin protein levels in C6 cells treated with GH $(25 \mu \mathrm{g} / \mathrm{ml})$ or GHRP- $6(25 \mu \mathrm{g} / \mathrm{ml})$ (C). The average of three $(C)$ or four ( $A$ and $B$ ) independent experiments performed in duplicate $(C)$ or in quadruplicate $(A$ and $B)$ is shown. Statistical significance by ANOVA: ${ }^{* * * P}<0.001$ vs control; ${ }^{*} P<0.05$ vs GHRP- 6 .

significant activation of STAT5 (control: $100 \pm 2.1$ and GH: $155.4 \pm 21.8 ; P<0.05$ ).

The levels of GRLN-R1a mRNA were undetectable at baseline; however, its expression increased after stimulation with 25 or $50 \mu \mathrm{g} / \mathrm{ml}$ of GHRP-6 (data not shown).

GH increased the levels of GFAP in C6 cells To further study the effect of $\mathrm{GH}$ on astrocytes, cells were treated with $25 \mu \mathrm{g} / \mathrm{ml} \mathrm{GH}$ for $24 \mathrm{~h}$. GH increased the levels of GFAP assayed by western blotting (146\% of control values). GHRP-6 did not affect the levels of GFAP (Fig. 4B).

To determine the specificity of GH acting through its specific receptor, C6 cells were treated with a blocking antibody specific to GHR. Co-treatment with GH and a blocking antibody to GHR reduced levels of GFAP (Fig. 4C).

GHRP-6 increased proliferation of $\mathbf{C} 6$ cells The crystal violet assay, used as a proliferation index, revealed an increase in cell number in response to $25 \mu \mathrm{g} / \mathrm{ml}$ GHRP-6 (135\% of control values). By contrast, treatment with GH had no effect on proliferation (Fig. 5A).

To determine the specificity of GHRP- 6 acting through its specific receptor, C6 cells were treated with D-Lys3-GHRP-6, an antagonist of the ghrelin receptor. Co-treatment with GHRP-6 and D-Lys3-GHRP-6 reversed the increase in cell number stimulated by GHRP-6 (Fig. 5B). Interestingly, treatment of cells with the antagonist alone increased the number of cells.

GH and GHRP-6 had no effect on vimentin levels in C6 cells Levels of vimentin (Fig. 6A) in C6 cells did not change in response to $25 \mu \mathrm{g} / \mathrm{ml}$ GH or GHRP-6.

Signalling pathways involved $\mathrm{GH}$ and GHRP- 6 increased the levels of IGF1 mRNA (196 and 235\% of control levels respectively $P<0.01$ ) in C6 cells. GH and GHRP-6 increased the levels of p-Akt (144 and 133\% of control values respectively) (Fig. 6A) but did not activate ERK1/2 (data not shown).

To confirm the involvement of the PI3K/Akt pathway, C6 cells were treated with LY294002, an inhibitor of PI3K, co-treatment of C6 cells with GH+LY294002 reduced the GFAP levels induced by GH (Fig. 6B) and co-treatment of C6 with GHRP-6+LY294002 reversed the increase in cell number induced by GHRP-6 (Fig. 6C).

\section{Discussion}

GH and ghrelin are important factors involved in the hypothalamic regulation of energy homoeostasis (Nyberg 2000, Nakazato et al. 2001) and in functions ascribed to the hippocampus such as learning and memory processes (Diano et al. 2006, Donahue et al. 2006). These two brain areas express GHR mRNA (Bennett et al. 1996, Minami et al. 2006) in different cells types including astrocytes (Lobie et al. 1993, Blackmore et al. 2012). GRLN-R1a is also located in both the CNS and the periphery (Zigman et al. 2006). It is also present in astrocytomas where it is

Published by Bioscientifica Ltd. 

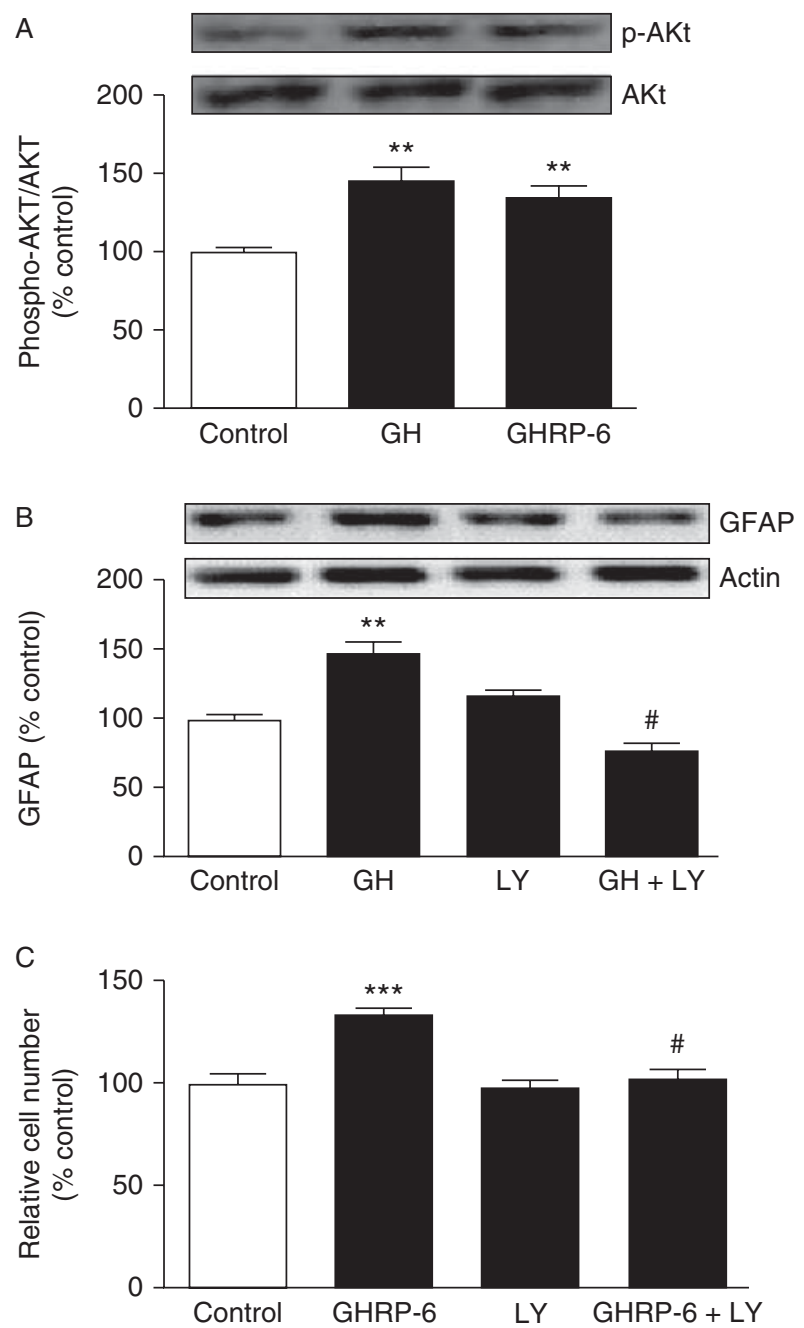

Figure 6

Relative p-Akt protein levels in C6 cells treated with $\mathrm{GH}(25 \mu \mathrm{g} / \mathrm{ml})$ or GHRP-6 $(25 \mu \mathrm{g} / \mathrm{ml})$ (A). Relative GFAP protein levels in C6 cells treated with $\mathrm{GH}(25 \mu \mathrm{g} / \mathrm{ml})$ or LY294002 (LY; $50 \mu \mathrm{M})$ (B). Quantification of cell viability assayed by crystal violet in C6 cells treated with GHRP-6 $(25 \mu \mathrm{g} / \mathrm{ml})$ or LY294002 $(50 \mu \mathrm{M})$. The average of three (A and B) or four $(C)$ independent experiments performed in duplicate (A and $B$ ) or in quadruplicate $(C)$ is shown. Statistical significance by ANOVA: ${ }^{* *} P<0.01$ and $* * * P<0.001$ vs control; ${ }^{\#} P<0.05$ vs GH or GHRP-6.

involved in cell motility (Dixit et al. 2006, Chen et al. 2011). In our study, we observed GHR and GRLN-R1a immunolabelling in astrocytes of the hypothalamic arcuate nucleus and of the dentate gyrus in the hippocampus. Although the role of GH and ghrelin in astrocytes remains unclear, it is known that hormonal actions in the brain are exerted through both neurons and glial cells. Glial cells express many of the same hormone receptors as found on neurons (García-Segura \& McCarthy 2004). In addition, labelling for GRLN-R1a was observed in tanycytes and in cells throughout the periventricular area.
In this study, we show that treatment with GH but not GHRP-6 increases the levels of GFAP in the hypothalamus and hippocampus of male rats. GFAP has been widely recognised as an astrocyte differentiation marker constituting the major intermediate filament protein of mature astrocyte (Galou et al. 1996, Freeman 2010). Modulators of GFAP expression include steroids, cytokines and growth factors (Laping et al. 1994, García-Segura \& McCarthy 2004). Overexpression of GH in transgenic mice increases GFAP levels (Miller et al. 1995). In our in vivo model, the observed increased expression of GFAP induced by GH was accompanied by a shift in electrophoretic mobility probably due to an increase in the levels of the phosphorylated forms of GFAP. GFAP phosphorylation contributes to stabilisation of GFAP and protects it from proteolytic degradation (Inagaki et al. 1990, 2008). Hence, phosphorylation of GFAP induced by GH may play important roles in astrocyte remodelling and could potentially contribute to the plasticity of the CNS (Takemura et al. 2002, Sullivan et al. 2012).

Here, we show that GH does not induce cell proliferation markers in the hypothalamus or hippocampus of adult rats. In fact, activation of the Gfap gene promoter has been related to decreased astrocyte proliferation (Gomes et al. 1999b). Although GH promotes the proliferation of neural precursors, neurogenesis and gliogenesis during brain development (Ajo et al. 2003), in our adult rats, GH did not induce proliferation but may induce astrocyte differentiation or activation. To further characterise the cellular differentiation stimulated by GH, we studied the levels of another protein of the cytoskeleton, vimentin. This protein is expressed in cells from mesenchymal origin and poorly differentiated (Mukhina et al. 2004), as well as activated astrocytes. In normal adult hypothalamus, the majority of vimentin is in the tanycytes. Here, we showed that the levels of vimentin were decreased in the hypothalamus and hippocampus of rats treated with GH, suggesting that the increase in GFAP is not due to astrocytic activation, while GHRP-6 had no effect on vimentin. An increase in GFAP levels (marker of mature astrocytes) and a decrease in vimentin levels (marker of immature astrocytes) after treatment with GH might indicate a change in the proteins forming the intermediate filaments of the astrocyte cytoskeleton, and, hence, GH might induce astrocyte maturation in the hypothalamus and in the hippocampus. Other hormones are also involved in similar cellular processes; for example, during development, $\mathrm{T} 3$ accelerates the transition from vimentin-positive to GFAP-positive cells in the forebrain and hippocampus with an increase in the intensity of

Published by Bioscientifica Ltd. 
GFAP immunoreactivity (Gould et al. 1990, Ghosh et al. 2005). Moreover, T3 can induce GFAP synthesis and astrocyte differentiation (Lima et al. 1997). Oestradiol also promotes differentiation of glial cells with a redistribution of GFAP in hypothalamic astrocytes (Torres-Aleman et al. 1992, Mong \& Blutstein 2006). In addition, the transforming growth factor $\beta$ has been reported to inhibit astrocyte proliferation and to induce the expression of GFAP in vivo (Reilly et al. 1998, Sousa et al. 2004) and in vitro (Laping et al. 1994).

Treatment with GHRP-6 did not increase GFAP levels but stimulated proliferation in the hypothalamus and hippocampus. GHRP-6 and ghrelin stimulate the proliferation of a wide number of cells including osteoblasts (Kim et al. 2005), cardiomyocytes (Pettersson et al. 2002), somatotrophs (Dieguez \& Casanueva 2000), endothelial cells (Rossi et al. 2009) and adipocytes (Thompson et al. 2004) and may also affect the CNS by protecting neurons from apoptosis (Frago et al. 2002, 2011, Delgado-Rubin de Célix et al. 2006, Delgado-Rubin et al. 2009). We also evaluated the possible effect of GH and GHRP-6 on neuron number and did not observed any changes in the levels of Tuj 1 in the hypothalamus or hippocampus.

In previous studies, we demonstrated that rats treated with GH or GHRP-6 showed increased levels of phosphorylated Akt but not of ERK1/2 in the hypothalamus, hippocampus and cerebellum (Frago et al. 2002); although in some circumstances, GH and ghrelin have been shown to activate not only the PI3K/Akt signalling pathway but also the MAPK pathway (Chung et al. 2007, Brooks et al. 2008, Andrews 2011). Thus, GH after binding to its receptor activates the PI3K/Akt signalling pathway (Frago et al. 2002), which could induce the activation and differentiation of astrocytes in the hypothalamus and hippocampus. By contrast, GHRP-6 binds to GRLN-R1a activating the PI3k/Akt pathway to promote proliferation in the hypothalamus and in the hippocampus confirming the paradigm largely established that Akt is a central regulator of survival, growth and proliferation (Pascual \& Guerri 2007). Many of the PI3K-dependent events are mediated by further downstream signalling pathways. Akt has been linked to the phosphorylation of the transcription factor Creb, which has been demonstrated to be activated by GH (Yarwood et al. 1998, Lobie et al. 2000, Zhu et al. 2001). Also ghrelin has been demonstrated to stimulate CREB in the hippocampus (Cuellar \& Isokawa 2011) and the hypothalamus (Petersen et al. 2009). Hence, CREB may be another key molecule involved in the roles of GH and GHRP-6.
The actions of GH and GHRP- 6 on proliferation and differentiation could be mediated by an increase in IGF1, which has been demonstrated to affect these processes (Åberg et al. 2000). To explore this question, we measured the levels of circulating IGF1 and we found that serum IGF1 levels did not increase in response to GH or GHRP-6 treatment. Some studies on healthy rats demonstrate that i.v. infusion of GH inhibits endogenous GH secretory pulses (Clark et al. 1988, Chan et al. 2006), possibly explaining why the plasma levels of IGF1 do not increase after a 7-day continuous infusion of GH. Similarly, Thompson et al. (2003) reported that a 7-day continuous infusion of GHRP-6 suppressed the amplitude of spontaneous GH secretory episodes and hence plasma levels of IGF1. However, we have previously reported that this same experimental protocol results in an increase in IGF1 mRNA levels in hypothalamus and hippocampus (Frago et al. 2002). Hence, increased local production of IGF1 could be involved in activation of these intracellular pathways.

The observed changes in glial proteins in response to i.v. treatments with GH and GHRP-6 may not be the result of direct actions of these factors on astrocytes; hence, we performed studies on $\mathrm{C} 6$ astrocytes to support that at least

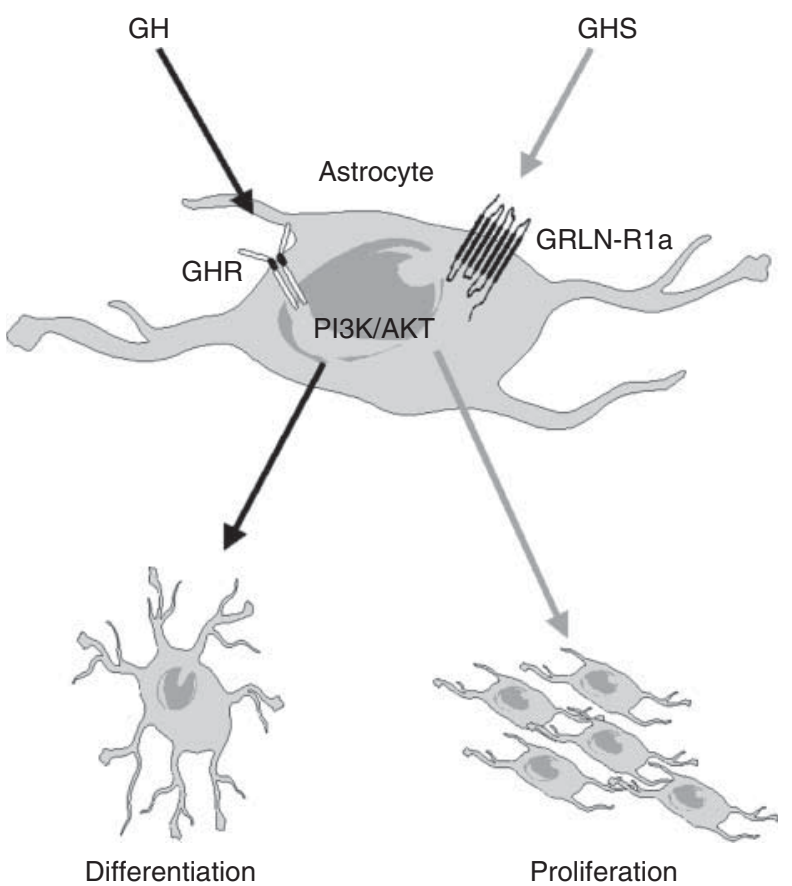

Figure 7

Diagram representing the effect of GH and GHRP- 6 on astrocytes. GH is proposed to induce differentiation acting through GHR and GHRP-6 to induce proliferation by binding GRLN-R1a on astrocytes. GH and GHRP-6 may act through activation of the PI3K/Akt pathway.

Published by Bioscientifica Ltd. 
some of these effects may indeed be mediated directly on astrocytes. It must be taken into consideration that the cells used are C6 astrocytes that derive from a tumour induced by $\mathrm{N}$-nitrosomethylurea. We demonstrated that these astrocytes responded to GH and GHRP- 6 by increasing the expression of their respective receptors. Moreover, GH increased the levels of GFAP and GHRP-6 increased proliferation of C6 cells, and these effects were specific as the presence of a blocking antibody against GH reversed the increase in GFAP levels induced by GH and D-Lys3-GHRP-6, an antagonist of GRLN-R1a, reduced the increase in cell number induced by GHRP-6. Interestingly, treatment of cells with the antagonist alone increased the number of cells. This is a paradoxical effect of the antagonist. In some studies using cell lines, D-Lys-GHRP-6 evoked a biphasic effect on proliferation, being inhibitory at $10^{-4} \mathrm{M}$ and stimulatory at $10^{-5}$ and $10^{-6} \mathrm{M}$ (Mucha \& Stepien 2002). In this study, D-Lys3-GHRP-6 was added at a dose of $27 \times 10^{-6} \mathrm{M}$, a concentration that could have a stimulatory effect. These observed paradoxical effects of DLys3-GHRP-6 suggest unknown underlying regulations of the ghrelin system whose understanding requires further investigation.

Similar to that observed in vivo (Frago et al. 2002), both treatments increased the mRNA levels of IGF1, activated Akt and had no effect on ERKS activation in C6 cells, and, more importantly, the treatment of $\mathrm{C} 6$ cells with the PI3K inhibitor, LY294002, reduced the GH-induced rise in GFAP levels and reversed the proliferation induced by GHRP-6. It is possible that the observed effects are mediated by IGF1, as both GH and GHRP-6 increase the levels of IGF1 mRNA in vivo (Frago et al. 2002) and in C6 astrocytes. Hence, a local increase in IGF1 levels could underlie the increase in Akt activation (Kulik \& Weber 1998).

In summary, this study demonstrates that the PI3K/Akt pathway has an important role in regulating cell proliferation and differentiation of astrocytes with $\mathrm{GH}$ inducing astrocyte differentiation and GHRP-6 stimulating their proliferation through this signalling pathway (Fig. 7).

\section{Declaration of interest}

The authors declare that there is no conflict of interest that could be perceived as prejudicing the impartiality of the research reported.

\section{Funding}

This study was funded by grants from Ministerio de Economía y Competitividad (BFU2008-02950 C03-3 and BFU2011-27492), Universidad Autónoma de Madrid-Comunidad de Madrid (CCG2008-UAM/SAL4451),

http://joe.endocrinology-journals.org DOI: $10.1530 / J O E-13-0053$
C 2013 Society for Endocrinology Printed in Great Britain
Fondo de Investigación Sanitaria (PI100747), CIBER de Fisiopatología de Obesidad y Nutrición (CIBEROBN) Instituto de Salud Carlos III and Fundación de Endocrinología y Nutrición. E B is supported by predoctoral fellowship from the Ministerio de Educación y Ciencia.

\section{Acknowledgements}

The authors thank Sandra Canelles and Francisa Díaz for excellent technical assistance.

\section{References}

Åberg MA, Åberg ND, Hedbäcker H, Oscarsson J \& Eriksson PS 2000 Peripheral infusion of IGF-I selectively induces neurogenesis in the adult rat hippocampus. Journal of Neuroscience 20 2896-2903.

Ajo R, Cacicedo L, Navarro C \& Sánchez-Franco F 2003 Growth hormone action on proliferation and differentiation of cerebral cortical cells from fetal rat. Endocrinology 144 1086-1097. (doi:10.1210/en.2002-220667)

Andrews ZB 2011 The extra-hypothalamic actions of ghrelin on neuronal function. Trends in Neuroscience 34 31-40. (doi:10.1016/j.tins.2010. 10.001)

Barres BA 1991 New roles for glia. Journal of Neuroscience 11 3685-3694.

Bennett PA, Levy A, Carmignac DF, Robinson IC \& Lightman SL 1996 Differential regulation of the growth hormone receptor gene: effects of dexamethasone and estradiol. Endocrinology 137 3891-3896. (doi:10.1210/en.137.9.3891)

Blackmore DG, Reynolds BA, Golmohammadi MG, Large B, Aguilar RM, Haro L, Waters MJ \& Rietze RL 2012 Growth hormone responsive neural precursor cells reside within the adult mammalian brain. Scientific Reports 2 250. (doi:10.1038/srep00250)

Brooks AJ, Wooh JW, Tunny KA \& Waters MJ 2008 Growth hormone receptor; mechanism of action. International Journal of Biochemistry \& Cell Biology 40 1984-1989. (doi:10.1016/j.biocel.2007.07.008)

Burman P \& Deijen J 1998 Quality of life and cognitive function in patients with pituitary insufficiency. Psychotherapy and Psychosomatics 67 154-167. (doi:10.1159/000012276)

Camiña JP, Carreira MC, Micic D, Pombo M, Kalestimur F, Dieguez C \& Casanueva FF 2003 Regulation of ghrelin secretion and action. Endocrine 22 5-12. (doi:10.1385/ENDO:22:1:5)

Chan CB, Tse MC \& Cheng CH 2006 Regulation and mechanism of growth hormone and insulin-like growth factor-I biosynthesis and secretion. In The Somatotrophic Axis in Brain Function, pp 7-23. Ed. Fred Nyberg. Burlington: Elsevier Academic Press.

Chen JH, Huang SM, Chen CC, Tsai CF, Yeh WL, Chou SJ, Hsieh WT \& Lu DY 2011 Ghrelin induces cell migration through GHS-R, CaMKII, AMPK and NF- $\kappa$ B signaling pathway in glioma cells. Journal of Cellular Biochemistry 112 2931-2941. (doi:10.1002/jcb.23209)

Chung H, Kim E, Lee DH, Seo S, Ju S, Lee D, Kim H \& Park S 2007 Ghrelin inhibits apoptosis in hypothalamic neuronal cells during oxygen-glucose deprivation. Endocrinology 148 148-159. (doi:10.1210/ en.2006-0991)

Clark RG, Carlsson LMS \& Robinson ICAF 1988 Growth hormone (GH) secretion in the conscious rat: negative feedback of GH on its own release. Journal of Endocrinology 119 201-209. (doi:10.1677/joe.0. 1190201)

Conway-Campbell BL, Wooh JW, Brooks AJ, Gordon D, Brown RJ, Lichanska AM, Chin HS, Barton CL, Boyle GM, Parsons PG et al. 2007 Nuclear targeting of the growth hormone receptor results in dysregulation of cell proliferation and tumorigenesis. PNAS 104 13331-13336. (doi:10.1073/pnas.0600181104)

Cuellar JN \& Isokawa M 2011 Ghrelin-induced activation of cAMP signal transduction and its negative regulation by endocannabinoids in the 
hippocampus. Neuropharmacology 60 842-851. (doi:10.1016/j.neuropharm.2010.12.024)

Davenport AP, Bonner TI, Foord SM, Harmar AJ, Neubig RR, Pin JP, Spedding M, Kojima M \& Kangawa K 2005 International Union of Pharmacology. LVI: ghrelin receptor nomenclature, distribution, and function. Pharmacological Reviews 57 541-546. (doi:10.1124/pr.57.4.1)

Deijen B, Arwert LI \& Drent ML 2011 The GH/IGF-I axis and cognitive changes across a 4-year period in healthy adults. ISRN Endocrinology 2011 249421. (doi:10.5402/2011/249421)

Delgado-Rubin A, Chowen JA, Argente J \& Frago LM 2009 Growth hormone releasing peptide- 6 protection of hypothalamic neurons from glutamate excitotoxicity is caspase independent and mediated by insulin-like growth factor I. European Journal of Neuroscience 29 2115-2124. (doi:10.1111/j.1460-9568.2009.06770.x)

Delgado-Rubin de Célix A, Chowen JA, Argente J \& Frago LM 2006 Growth hormone releasing peptide- 6 acts as a survival factor in glutamateinduced excitotoxicity. Journal of Neurochemistry 99 839-849. (doi:10.1111/j.1471-4159.2006.04122.x)

Diano S, Farr SA, Benoit S, McNay EC, da Silva I, Horvath B, Gaskin FS, Nonaka N, Jaeger LB, Banks WA et al. 2006 Ghrelin controls hippocampal spine synapse density and memory performance. Nature Neuroscience 9 381-388. (doi:10.1038/nn1656)

Dieguez C \& Casanueva FF 2000 Ghrelin: a step forward in the understanding of somatroph cell function and growth regulation. European Journal of Endocrinology 142 413-417. (doi:10.1530/eje.0.1420413)

Dixit VD, Weeraratna AT, Tang H, Bertak D, Cooper-Jenkins A, Riggins GJ, Eberhart CG \& Taub DD 2006 Ghrelin and the growth hormone secretagogue receptor constitute a novel autocrine pathway in astrocytoma motility. Journal of Biological Chemistry 24 16681-16690. (doi:10.1074/jbc.M600223200)

Donahue CP, Kosik KS \& Shors TJ 2006 Growth hormone is produced within the hippocampus where it responds to age, sex and stress. PNAS 103 6031-6036. (doi:10.1073/pnas.0507776103)

Frago LM, Pañeda C, Dickson SL, Hewson AK, Argente J \& Chowen JA 2002 Growth hormone $(\mathrm{GH})$ and $\mathrm{GH}$-releasing peptide- 6 increase brain insulin-like growth factor-I expression and activate intracellular signaling pathways involved in neuroprotection. Endocrinology 143 4113-4122. (doi:10.1210/en.2002-220261)

Frago LM, Baquedano E, Argente J \& Chowen JA 2011 Neuroprotective actions of ghrelin and growth hormone secretagogues. Frontiers in Molecular Neuroscience 4 23. (doi:10.3389/fnmol.2011.00023)

Fraser RA, Attardo D \& Harvey S 1990 Growth hormone receptors in hypothalamic and extra-hypothalamic tissues. Journal of Molecular Endocrinology 5 231-238. (doi:10.1677/jme.0.0050231)

Freeman MR 2010 Specification and morphogenesis of astrocytes. Science 330 774-778. (doi:10.1126/science.1190928)

Galou M, Colucci-Guyon E, Ensergueix D, Ridet JL, Gimenez y Ribotta M, Privat A, Babinet C \& Dupouey P 1996 Disrupted glial fibrillary acidic protein network in astrocytes from vimentin knockout mice. Journal of Cell Biology 133 853-863. (doi:10.1083/jcb.133.4.853)

García-Segura LM \& McCarthy MM 2004 Minireview: role of glia in neuroendocrine function. Endocrinology 145 1082-1086. (doi:10.1210/ en.2003-1383)

Ghigo E, Arvat E, Giordano R, Broglio F, Gianotti L, Maccario M, Bisi G, Graziani A, Papotti M, Muccioli G et al. 2001 Biological activities of growth hormone secretagogues in humans. Endocrine 14 87-93. (doi:10.1385/ENDO:14:1:087)

Ghosh M, Gharami K, Paul S \& Das S 2005 Thyroid hormone-induced morphological differentation and maturation of astrocytes involves activation of protein kinase A and ERK signaling pathway. European Journal of Neuroscience 22 1609-1617. (doi:10.1111/j.1460-9568.2005. 04351.x)

Gomes FCA, Paulin D \& Moura-Neto V 1999a Glial fibrilary acidic protein (GFAP): modulation by growth factors and its implication in astrocyte differentiation. Brazilian Journal of Medical and Biological Research 32 619-631. (doi:10.1590/S0100-879X1999000500016)
Gomes FCA, Garcia-Abreu J, Galou M, Paulin D \& Moura Neto V 1999b Neurons induce GFAP gene promoter of cultured astrocytes from transgenic mice. Glia 26 97-108. (doi:10.1002/(SICI)1098-

1136(199904)26:2<97::AID-GLIA1 > 3.0.CO;2-Z)

Gould E, Frankfurt M, Westlind-Danieldsson A \& McEwen BS 1990 Developing forebrain astrocytes are sensitive to thyroid hormone. Glia 3 283-292. (doi:10.1002/glia.440030408)

Harvey S, Hull KL \& Fraser RA 1993 Growth hormone: neurocrine and neuroendocrine perspectives. Growth Regulation 3 161-171.

Inagaki M, Gonda Y, Nishizawa K, Kitamura S, Sato C, Ando S, Tanabe K, Kikuchi K, Tsuiki S \& Nishi Y 1990 Phosphorylation sites linked to glial filament disassembly in vitro locate in a non-alpha-helical head domain. Journal of Biological Chemistry 265 4722-4729.

Inagaki M, Imakamura Y, Takeda M, Nishimura T \& Inagaki N 2008 Glial fibrilary acidic protein: dynamic property and regulation by phosphorylation. Brain Pathology 4 239-243. (doi:10.1111/j.1750-3639.1994.tb00839.x)

Järlestedt K, Rousset CI, Faiz M, Wilhelmsson U, Ståhlberg A, Sourkova H, Pekna M, Mallard C, Hagberg H \& Pekny M 2010 Attenuation of reactive gliosis does not affect infarct volume in neonatal hypoxicischemic brain injury in mice. PLoS ONE 5 e10397. (doi:10.1371/ journal.pone.0010397)

Kim SW, Her SJ, Park SJ, Kim D, Park KS, Lee HK, Han BH, Kim MS, Shin CS \& Kim SY 2005 Ghrelin stimulates proliferation and differentiation and inhibits apoptosis in osteoblastic MC3T3-E1 cells. Bone 37 359-369. (doi:10.1016/j.bone.2005.04.020)

Kulik G \& Weber MJ 1998 Akt-dependent and independent survival signalling pathways utilized by insulin-like growth factor. Molecular and Cellular Biology 18 6711-6718.

Lanning NJ \& Carter-Su C 2006 Recent advances in growth hormone signalling. Reviews in Endocrine \& Metabolic Disorders 7 225-235. (doi:10.1007/s11154-007-9025-5)

Laping NJ, Teter B, Nichols NR, Rozovsky I \& Finch CE 1994 Glial fibrillary acidic protein: regulation by hormones, cytokines and growth factors. Brain Pathology 4 259-275. (doi:10.1111/j.1750-3639.1994.tb00841.x)

Le Greves M, Le Greves P \& Nyberg F 2005 Age-related effects of IGF-1 on the NMDA-, GH- and IGF-1-receptor mRNA transcript in the rat hippocampus. Brain Research Bulletin 15 369-374. (doi:10.1016/ j.brainresbull.2005.01.012)

Lichanska AM \& Waters MJ 2008 New insights into growth hormone receptor function and clinical implications. Hormone Research 69 138-145. (doi:10.1159/000112586)

Lima FRS, Trentin AG, Rosenthal D, Chagas C \& Moura Neto V 1997 Thyroid hormone induces protein secretion and morphological changes in astroglial cells with an increase in expression of glial fibrillary acidic protein. Journal of Endocrinology 154 167-175. (doi:10.1677/joe.0.1540167)

List EO, Sackmann-Sala L, Berryman DE, Funk K, Kelder B, Gosney ES, Okada S, Ding J, Cruz-Topete D \& Kopchick JJ 2011 Endocrine parameters and phenotypes of the growth hormone receptor gene disrupted (GHR -/-) mouse. Endocrine Reviews 32 356-386. (doi:10.1210/er.2010-0009)

Lobie PE, García-Aragón J, Lincoln DT, Barnard R, Wilcox JN \& Waters MJ 1993 Localization and ontogeny of growth hormone receptor gene expression in the central nervous system. Developmental Brain Research 74 225-233. (doi:10.1016/0165-3806(93)90008-X)

Lobie PE, Zhu T, Graichen R \& Goh ELK 2000 Growth hormone, insulinlike growth factor I and the CNS: localization, function and mechanism of action. Growth Hormone \& IGF Research 10 S51-S56. (doi:10.1016/ S1096-6374(00)80010-6)

Lyuh E, Kim HJ, Kim M, Lee JK, Park KS, Yoo KY, Lee KW \& Ahn YO 2007 Dose-specific or dose-dependent effect of growth hormone treatment on the proliferation and differentiation of cultured neuronal cells. Growth Hormone \& IGF Research 17 315-322. (doi:10.1016/j.ghir.2007.03.002)

McLenachan S, Gum M-G, Waters MJ \& Turnley AM 2009 Growth hormone promotes proliferation of adult neurosphere cultures. Growth Hormone \& IGF Research 19 212-218. (doi:10.1016/j.ghir.2008.09.003) 
Miller DB, Bartke A \& O'Callaghan JP 1995 Increased glial fibrillary acidic protein (GFAP) levels in the brains of transgenic mice expressing the bovine growth hormone (bGH) gene. Experimental Gerontology 30 383-400. (doi:10.1016/0531-5565(94)00064-A)

Minami S, Kamegai J, Hasegawa O, Sugihara H, Okada K \& Wakabayashi I 2006 Expression of growth hormone receptor gene in rat hypothalamus. Journal of Neurochemistry 5 691-696.

Mong JA \& Blutstein T 2006 Estradiol modulation of astrocytic form and function: implication for hormonal control of synaptic communication. Neuroscience 138 967-975. (doi:10.1016/j.neuroscience.2005. 10.017)

Muccioli G, Baragli A, Granata A, Papotti M \& Ghigho E 2007 Heterogeneity of ghrelin/growth hormone secretagogue receptors. Neuroendocrinology 86 147-164. (doi:10.1159/000105141)

Mucha S \& Stepien H 2002 Modulation of ghrelin axis influences the growth of colonic and prostatic cancer cells in vitro. Pharmacological Reports 64 951-959.

Mukhina S, Mertani HC, Guo K, Lee KO, Gluckman PD \& Lobie PE 2004 Phenotypic conversion of human mammary carcinoma cells by autocrine human growth hormone. PNAS 101 15166-15171. (doi:10.1073/pnas.0405881101)

Nakazato M, Murakami N, Date Y, Kojima M, Matsuo H, Kangawa K \& Matsukura S 2001 A role for ghrelin in the central regulation of feeding. Nature 409 194-198. (doi:10.1038/35051587)

Nyberg F 2000 Growth hormone in the brain: characteristics of specific brain targets for the hormone and their functional significance. Frontiers in Neuroendocrinology 21 330-348. (doi:10.1006/frne.2000. 0200)

Pascual M \& Guerri C 2007 The peptide NAP promotes neuronal growth and differentiation through extracellular signal-regulated protein kinase and Akt pathways, and protects neurons co-cultured with astrocytes damaged by ethanol. Journal of Neurochemistry 103 557-568. (doi:10.1111/j.1471-4159.2007.04761.x)

Perea G \& Araque A 2005 Synaptic regulation of the astrocyte calcium signal. Journal of Neural Transmission 112 127-135. (doi:10.1007/ s00702-004-0170-7)

Petersen PS, Woldbye DP, Madsen AN, Egerod KL, Jin C, Lang M \& Holst B 2009 In vivo characterization of high basal signalling from the ghrelin receptor. Endocrinology 150 4920-4930. (doi:10.1210/en.2008-1638)

Petersenn S 2002 Structure and regulation of the growth hormone secretagogue receptor. Minerva Endocrinologica 27 243-256.

Pettersson I, Muccioli G, Granata R, Deghenghi R, Ghigo E, Ohlsson C \& Isgaard J 2002 Natural (ghrelin) and synthetic (hexalerin) GH secretagogues stimulate $\mathrm{H} 9 \mathrm{c} 2$ cardiomyocyte cell proliferation. Journal of Endocrinology 175 201-209. (doi:10.1677/joe.0.1750201)

Reilly JF, Maher PA \& Kumari VG 1998 Regulation of astrocyte GFAP expression by TGF- $\beta 1$ and FGF-2. Glia 22 202-210. (doi:10.1002/ (SICI)1098-1136(199802)22:2<202::AID-GLIA11 > 3.0.CO;2-1)
Rossi F, Castelli A, Bianco MJ, Bertone C, Brama M \& Santiemma V 2009 Ghrelin inhibits contraction and proliferation of human aortic smooth muscle cells by cAMP/PKA pathway activation. Atherosclerosis $\mathbf{2 0 3}$ 97-104. (doi:10.1016/j.atherosclerosis.2008.06.015)

Scheepens A, Sirimanne E, Beilharz E, Breier BH, Waters MJ, Gluckman PD \& Williams CE 1999 Alterations in the neural growth hormone axis following hypoxic-ischemic brain injury. Molecular Brain Research 68 88-110. (doi:10.1016/S0169-328X(99)00051-0)

Sousa V de O, Romao L, Neto VM \& Gomes FC 2004 Glial fibrillary acidic protein gene promoter is differently modulated by transforming growth factor- $\beta 1$ in astrocytes from distinct brain regions. European Journal of Neuroscience 19 1721-1730. (doi:10.1111/j.1460-9568.2004. 03249.x)

Stoving RK, Veldhuis JD, Flyvgjerg A, Vinten J, Hangaard J, Koldjaer OG, Kristiansen J \& Hagen C 1999 Jointly amplified basal and pulsatile growth hormone secretion and increased process irregularity in women within the GH-insulin-like growth factor I axis. Journal of Clinical Endocrinology and Metabolism 84 2056-2063. (doi:10.1210/ jc.84.6.2056)

Sullivan SM, Sullivan RKP, Miller SM, Ireland Z, Björkman T, Pow DV \& Colditz PB 2012 Phosphorylation of GFAP is associated with injury in the neonatal pig hypoxic-ischemic brain. Neurochemical Research $\mathbf{3 7}$ 2364-2378. (doi:10.1007/s11064-012-0774-5)

Takemura M, Gomi H, Colucci-Guyon E \& Itohara S 2002 Protective role of phosphorylation in turnover of glial fibrillary acidic protein in mice. Journal of Neuroscience 22 6972-6979.

Thompson NM, Davies JS, Mode A, Houston PA \& Wells T 2003 Patterndependent suppression of growth hormone (GH) pulsatility by ghrelin and GH-releasing peptide-6 in moderately GH-deficient rats. Endocrinology 144 4859-4867. (doi:10.1210/en.2003-0423)

Thompson NM, Gill DAS, Davies R, Loveridge N, Houston PA, Robinson LCAF \& Wells T 2004 Ghrelin and des-octanoyl ghrelin promote adipogenesis directly in vivo by a mechanism independent of the type 1a growth hormone secretagogue receptor. Endocrinology $\mathbf{1 4 5}$ 234-242. (doi:10.1210/en.2003-0899)

Torres-Aleman I, Rejas MT, Pons S \& Garcica-Segura LM 1992 Estradiol promotes cell shape changes and glial fibrillary acidic protein redistribution in hypothalamic astrocytes in vitro: a neuronal-mediated effect. Glia 6 180-187. (doi:10.1002/glia.440060305)

Yarwood SJ, Kilgour E \& Anderson NG 1998 Cyclic AMP potentiates growth hormone-dependent differentiation of 3T3-F442A preadipocytes: possible involvement of the transcription factor CREB. Molecular and Cellular Endocrinology 138 41. (doi:10.1016/S0303-7207(98)00049-5)

Zhu T, Goh EL, Graichen R, Ling L \& Lobie PE 2001 Signal transduction via the growth hormone receptor. Cellular Signalling 13 599-616. (doi:10.1016/S0898-6568(01)00186-3)

Zigman JM, Jones JE, Lee CE, Saper CB \& Elmquist JK 2006 Expression of ghrelin receptor mRNA in the rat and the mouse brain. Journal of Comparative Neurology 494 528-548. (doi:10.1002/cne.20823)

Received in final form 31 May 2013

Accepted 21 June 2013

Accepted Preprint published online 21 June 2013 http://joe.endocrinology-journals.org DOI: 10.1530/JOE-13-0053
() 2013 Society for Endocrinology Printed in Great Britain
Published by Bioscientifica Ltd 